\title{
Glacier variations in response to climate change from 1972 to 2007 in the western Lenglongling mountains, northeastern Tibetan Plateau
}

\author{
Baotian PAN, Bo CAO, Jie WANG, Guoliang ZHANG, Chen ZHANG, Zhenbo HU, \\ Bo HUANG
}

\author{
Key Laboratory of Western China's Environmental Systems, Lanzhou University, Lanzhou, China \\ E-mail: caobo04@gmail.com
}

\begin{abstract}
Global warming is causing widespread glacier retreat, with small glaciers disappearing. We investigate changes in glaciers over the western Lenglongling mountains, located in the northeastern margin of the Tibetan Plateau. Glacier extent over the western Lenglongling mountains is estimated by comparing digitized glacier outlines obtained from aerial photographs and satellite imagery. These results suggest that all 179 glaciers in the western Lenglongling mountains shrunk between 1972 and 2007. The total area loss was $\sim 24.4 \mathrm{~km}^{2}$, accounting for $\sim 28.3 \%\left(0.81 \% \mathrm{a}^{-1}\right)$ of the glacierized area in 1972. The average area retreat rates differ over different time intervals: they are approximately 0.68 , $0.90,0.77$ and $0.56 \mathrm{~km}^{2} \mathrm{a}^{-1}$ over the periods 1972-95, 1995-99, 1999-2002 and 2002-07, respectively. Based on analysis of meteorological data, glacier shrinkage in the study area can probably be attributed to the increase in air temperature. Furthermore, the smaller glaciers display a higher shrinkage rate than larger glaciers, and glaciers on southwest-facing slopes appear to retreat faster than those on northeastfacing slopes.
\end{abstract}

\section{INTRODUCTION}

Changes in mountain glaciers are generally considered one of the best natural indicators of climatic change (Pachauri and Reisinger, 2007). Glaciers and ice caps are also believed to have a significant effect on global sea levels (e.g. Fairbanks, 1989; Berthier and others, 2010) and thus they have been selected as one of the fundamental climate indicators in the Global Climate Observing System (GCOS, 2003). Over the past five decades, most of the world's glaciers have shown a tendency to shrink (Hall and others, 1995a; Vuille and others, 2008) and, recently, numerous relatively small glaciers have even completely disappeared (e.g. Delgado Granados and others, 2007; Dyurgerov and Meier, 1997). According to previous studies, more than $80 \%$ of the glaciers in China may be retreating (e.g. Liu and others, 2003; Jin and others, 2005; Shangguan and others, 2006). Numerical simulations of the response of these glaciers have also suggested that they will probably shrink further under increasingly warm conditions in the future (Oerlemans and others, 1998; Shi and Liu, 2000).

Compared with the detailed studies of glaciers in the European Alps (e.g. Berthier and others, 2005; Paul and others, 2007) or the Greenland and Antarctic ice sheets (e.g. Davis and others, 2005), studies on glacier changes in the Lenglongling mountains are rare. To our knowledge, there are only two published papers concerning glacier changes in the Lenglongling mountains, both in Chinese (Cao and others, 2010; Zhang and others, 2010a), and the data accuracy described in those papers does not meet the requirements of the Global Land Ice Measurements from Space (GLIMS) project. Changes in glaciers in the northeastern margin of the Tibetan Plateau indicate a sensitive response to global climate change (Liu and others, 2003; Shangguan and others, 2010). Studies of these glacier variations will provide valuable information concerning glacier response to climate change in the Tibetan Plateau and globally. In addition, glaciers within our study area are a significant freshwater resource for hydropower generation, irrigation and domestic and animal consumption in the Gansu corridor (Yang and Zeng, 2001). Accurate studies of glacier change and how climatic factors impact on the retreat of glaciers are therefore necessary and urgent in this area.

Over the past decade, remote-sensing satellite techniques have been widely adopted in investigations of mountain glaciers (e.g. Racoviteanu and others, 2008a; Paul and Andreassen, 2009). Satellite imagery that can distinguish between glacier area, seasonal snow cover and clouds can be employed to evaluate glacier change in areas that are difficult to access. The GLIMS project evaluates the extent and change of glaciers globally using satellite multispectral images (http://www.glims.org/), which are primarily obtained from the Advanced Spaceborne Thermal Emission and Reflection Radiometer (ASTER) and Landsat Enhanced Thematic Mapper Plus (ETM+) (Raup and others, 2007). Previous work has mainly concentrated on large-scale glaciers, whereas many small glaciers that are relatively inaccessible receive little attention, even though they are more sensitive to global climate change (Delgado Granados and others, 2007). According to Paul and others (2007), relatively small glaciers can be readily investigated repeatedly using remote-sensing techniques. A series of multispectral satellite data generated in the period 1995-2007 are investigated in this paper, aimed at analyzing the shrinkage mechanisms of the remote, relatively small glaciers of the northeastern Tibetan Plateau.

Aerial photographs, Landsat Thematic Mapper (TM), ETM+ and ASTER satellite data across the western Lenglongling mountains are used to reconstruct an archive of glacier change in the study area using GIS and digital imageprocessing technology as described by Paul and others (2007) and Shangguan and others (2007). These data are 


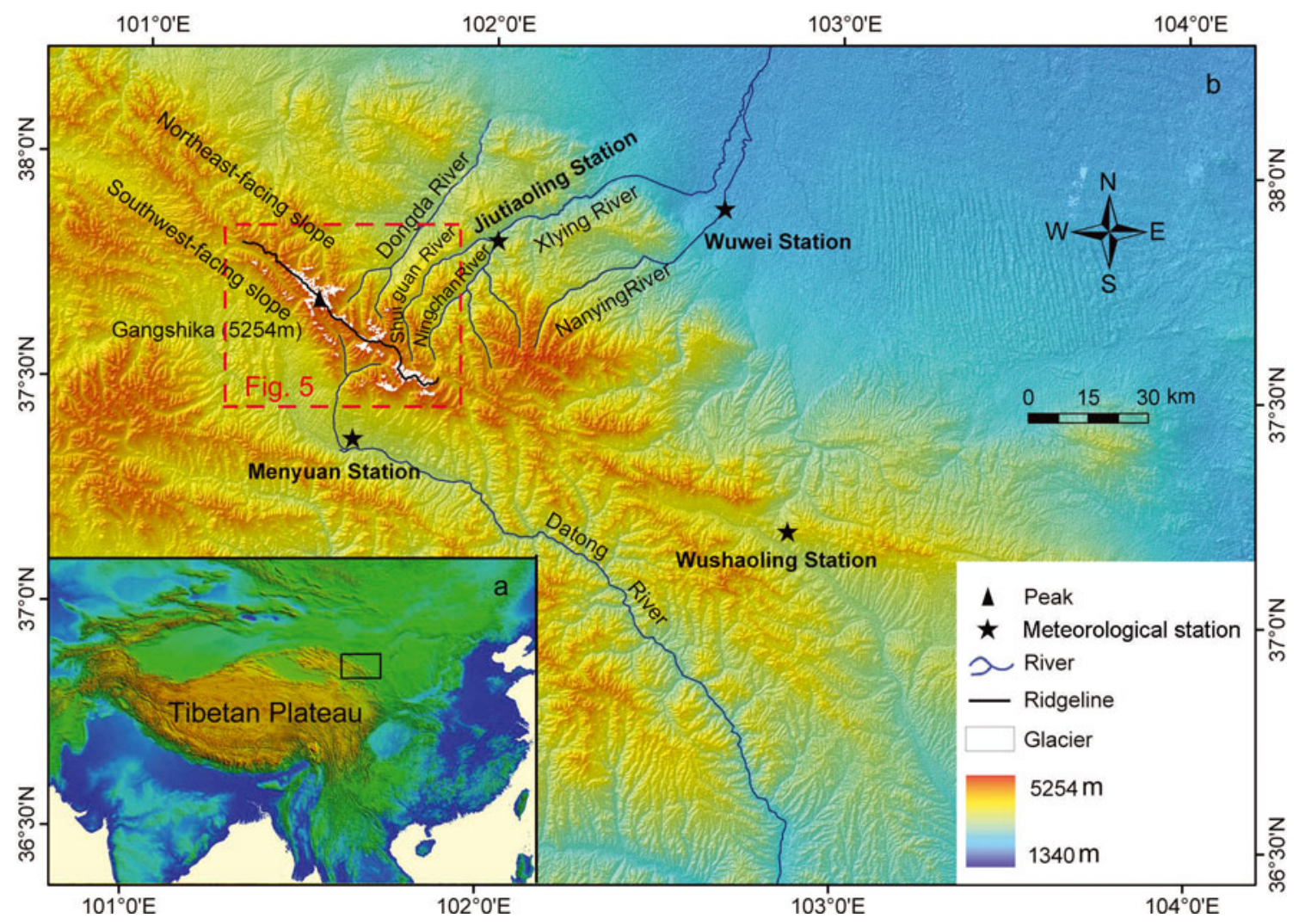

Fig. 1. Topographic map of the western Lenglongling mountains. (a) The inset shows the location of the mountains within the Tibetan Plateau. (b) Overview of the western Lenglongling mountains based on SRTM3-DEM. The ridgeline across the glaciers is outlined. The glaciers can be divided into two categories by the ridgeline: those on the southwest-facing slope and those on the northeast-facing slope.

then integrated with glacier size and meteorological information in order to understand the shrinkage of 179 glaciers in this region during the past 35 years.

\section{STUDY AREA}

The western Lenglongling mountains are located in the northeastern part of the Tibetan Plateau and are about $250 \mathrm{~km}$ in length and $30-50 \mathrm{~km}$ in width (Fig. 1). The mean altitude is $>4000 \mathrm{~m}$ and Gangshika peak is $5254 \mathrm{~m}$ a.s.l. Climatically, the area exhibits arid to semi-arid conditions. Glaciers of the western Lenglongling mountains are classified as subcontinental (subpolar)-type glaciers (Shi and Liu, 2000) and are influenced by the combined effects of the east Asian monsoon, the south Asian monsoon and westerlies (Tang and Xu, 1984).

Mean annual air temperature in the period 1957-2010 was $\sim 1^{\circ} \mathrm{C}$ at Menyuan meteorological station (2924 m a.s.I.). The mean equilibrium-line attitude (ELA) is $\sim 4500 \mathrm{~m}$ in the western Lenglongling mountains (Wang and others, 1981) and, extrapolating with a standard atmospheric lapse rate of $0.72^{\circ} \mathrm{C}(100 \mathrm{~m})^{-1}$ (Wang and others, 2009), mean annual air temperature at the ELA is $\sim-10^{\circ} \mathrm{C}$.

The Chinese Glacier Inventory (CGI) (Wang and others, 1981; Shi and others, 2005) shows that a total of 179 continental-type glaciers occur above $4000 \mathrm{~m}$ a.s.l. in the western Lenglongling mountains, covering a total area of $\sim 87.2 \mathrm{~km}^{2}$ (i.e. an average glacier area of $\sim 0.49 \mathrm{~km}^{2}$; Fig. 1). On the southwest-facing slope of the western Lenglongling mountains, there are 103 glaciers feeding the drainage basin of the Datong River, a tributary of the Yellow River. The average glacier area is $\sim 0.38 \mathrm{~km}^{2}$. The remaining
76 glaciers dominate the northeast-facing slope and are the source of some inland drainage basins. The average area of these glaciers is $\sim 0.63 \mathrm{~km}^{2}$.

\section{DATA AND METHODS}

\section{Topographical/aerial photograph map data}

We obtained from the State Bureau of Surveying and Mapping a series of 1:50000 topographical maps of the study area, originally generated from aerial photographs taken in 1972. We then digitized the 20 and $40 \mathrm{~m}$ interval contours and spot heights in order to generate a triangular irregular networks (TIN) map and to create a digital elevation model (DEM) based on Beijing54 using ArcGIS software. The center and flattening of Beijing54 are different from the World Geodetic System 1984 ellipsoidal elevation (WGS84) Universal Transverse Mercator (UTM). In order to compare with those data, the DEM was reprojected to the WGS84 UTM using a seven-parameter datum transformation model. The application of the seven-parameter datum transformation model has been discussed by Guo and others (2002), Wang and others (2003) and Zhang and others (2010b). The error using a seven-parameter datum transformation model is $<0.002 \mathrm{~m}$ (Wang and others, 2003).

However, taking into account the inevitable errors of glacier borderline in the process of generation from aerial photographic to topographical map (Hall and others, 2003), original aerial photographs were employed directly in order to identify the precise glacier outline or other surface types (e.g. Van Westen and Lulie Getahun, 2003; Andreassen and others, 2008). Fortunately, a total of 552 aerial photographs 
taken in 1972 exactly cover the western Lenglongling mountains. They were scanned and georectified using the DEM and a set of ground-control points (GCPs) for comparison with the topographical maps. These GCPs were selected from distinguishable landmarks present in the aerial photograph, such as summits, peninsulas and geologic patterns. The aerial photographs were resampled to $5 \mathrm{~m}$ resolution and the rectification error was $<2$ pixels $(10 \mathrm{~m})$ root-mean-square ( $r m s)$. The identified glacier outline was then digitized using GIS based on vector files.

\section{Remote-sensing data}

One TM image (path 132, row 34, 11 June 1995), two ETM+ images (path 132, row 34, 1 August 1999 and path 132, row 34, 24 July 2002) and an ASTER image (16 May 2007) (Table 1) were selected to investigate the dynamic changes of the 179 glaciers in the study area during different time intervals. Some regions could not be covered by a single scene, so it was necessary to develop a mosaic of several scenes from different years (Paul and Andreassen, 2009). Apart from the ETM+ image in 1999, the remaining four satellite scenes are free of cloud and seasonal snow cover. According to image pretreatment, most of the ETM+ in 1999 can also avoid interference from snow and cloud; nevertheless a small central part in this image suffered from slight interference by cloud. This section was therefore replaced by a China-Brazil Earth Resources Satellite (CBERS) image (path 15, row 58, 15 July 2000). For the western Lenglongling mountains, the glacier borderline in 1999 was estimated from the merged vector polygons, which were outlined by the two images independently. The TM, ETM+ and ASTER data were obtained from the Global Land Cover Facility (GLCF) and United States Geological Survey (USGS), while the CBERS data are from the China Center for Resources Satellite Data and Application. They were all orthorectified to the WGS84 UTM datum.

There are several fusion methods, for example principal components analysis (PCA), smoothing filter-based intensity modulation (SFIM), Brovey transform and intensity-huesaturation (IHS), which can be used to enhance the resolution and image interpretability of ETM+ data (Liu, 2000; Yang and others, 2007). However, enhancing spatial resolution and improving spectral characteristics are mutually contradictory, and, according to Yang and others (2007), the PCA method of enhancing spatial resolution retains the greatest degree of spectral characteristics. We use band 5, 4, 3 (as red, green, blue) false-colour compositing, then fuse the image with the panchromatic band by the PCA method with $28.5 \mathrm{~m}$ resolution multispectral data and $14.25 \mathrm{~m}$ resolution panchromatic data, yielding effectively a $14.25 \mathrm{~m}$ resolution multispectral image (Lillesand and Kiefer, 1999; Jiang and others, 2004). The resultant sensor resolutions of TM, ETM+, CBERS and ASTER are 28.50, $14.25,19.60$ and $15.00 \mathrm{~m}$, respectively.

In previous work, the methods for glacier delineation with Landsat data can generally be divided into three distinct groups: supervised classification (Aniya and others, 1996; Sidjak and Wheate, 1999), normalized-difference snow index (NDSI) (Hall and others, 1995b; Racoviteanu and others, 2008b) and segmentation of ratio images from various TM band combinations (Paul, 2001). Among these algorithms, the band ratio method, which has been adopted for many glacierized areas (e.g. Paul, 2001; Bolch, 2007; Paul and Andreassen, 2009), is considered the most accurate
Table 1. Overview of the data sources applied

\begin{tabular}{lccrc}
\hline Data source & Date & Path/row & $\begin{array}{c}\text { Resolution } \\
\mathrm{m}\end{array}$ & $\begin{array}{c}\mathrm{rmse}^{\dagger} \\
\mathrm{m}\end{array}$ \\
& & & & \\
\hline Topographical maps & 1972 & & 5.00 & \\
Aerial photographs & 1972 & & 5.00 & 10.00 \\
Landsat TM & Jun 1995 & $132 / 34$ & 28.50 & 28.50 \\
Landsat ETM+ & Aug 1999 & $132 / 34$ & 14.25 & 14.25 \\
CBERS* & Jul 2000 & $15 / 58$ & 19.60 & 19.60 \\
Landsat ETM+ & Jul 2002 & $132 / 34$ & 14.25 & 14.25 \\
ASTER & May 2007 & & 15.00 & 15.00 \\
& & & & \\
\hline
\end{tabular}

*According to the criteria of the State Bureau of Surveying and Mapping of China the ground resolution of maps at scales of $1: 50000$ is $\sim 5 \mathrm{~m}$.

The rmse of aerial photographs is $<2$ pixels, and that of remote-sensing images is $<1$ pixel.

and convenient algorithm to extract glacier borderlines. We also use this method to extract glacier borderlines from satellite images across the western Lenglongling mountains.

The processing chain for extracting glacier outlines from images is composed of four steps: (1) calculation of band ratio, (2) selection of threshold value, (3) creation of binary image and (4) manual digitization.

\section{Calculation of band ratio}

The band ratio method is based on the fact that ice has a high reflectivity of visible spectrum and a low reflectivity of shortwave infrared (SWIR) spectrum. Utilizing this, we can clearly distinguish glacier from other surface types. For Landsat imagery, according to the difference in glacier size and image content (shadow, vegetation, water), there are two band ratios that can be used (Paul and others, 2007): (1) TM3/TM5 (Narama and others, 2006; Paul and Andreassen, 2009) and (2) TM4/TM5 (Bolch, 2007; Shangguan and others, 2007). For the 179 glaciers studied in the western Lenglongling mountains, TM4/TM5 is more effective than TM3/TM5 in distinguishing glacier from other surface types. TM4/TM5 is thus adopted in this paper as the primary method to extract glacier outlines. Since the wavelengths of ASTER in bands 3 and 4 approximate those of Landsat in bands 4 and 5, TM3/TM4 was used to deal with ASTER data. The CBERS imagery has no SWIR band, so the glacier outlines were extracted based on manual digitization rather than the band ratio method.

\section{Selection of threshold value}

Thresholds appear to be different in different regions, also depending on the image content (Paul and others, 2007). Shangguan and others (2007) selected a value of 2.1 as a threshold in the western Kunlun Shan, Bolch (2007) considered 2.0 as a threshold in the Tien Shan, while Paul and Andreassen (2009) used 2.6 as a threshold in the Svartisen region, Norway. On the basis of repeated experiments, a threshold set to 2.3 will clearly distinguish glaciers from other surface types.

\section{Creation of binary image}

If the value of the ratio image exceeds the threshold value, the study object can be identified as a glacier or vice versa. That is, a value of 0 is assigned to pixels with a ratio less than the threshold, and a value of 1 to pixels with a ratio greater 

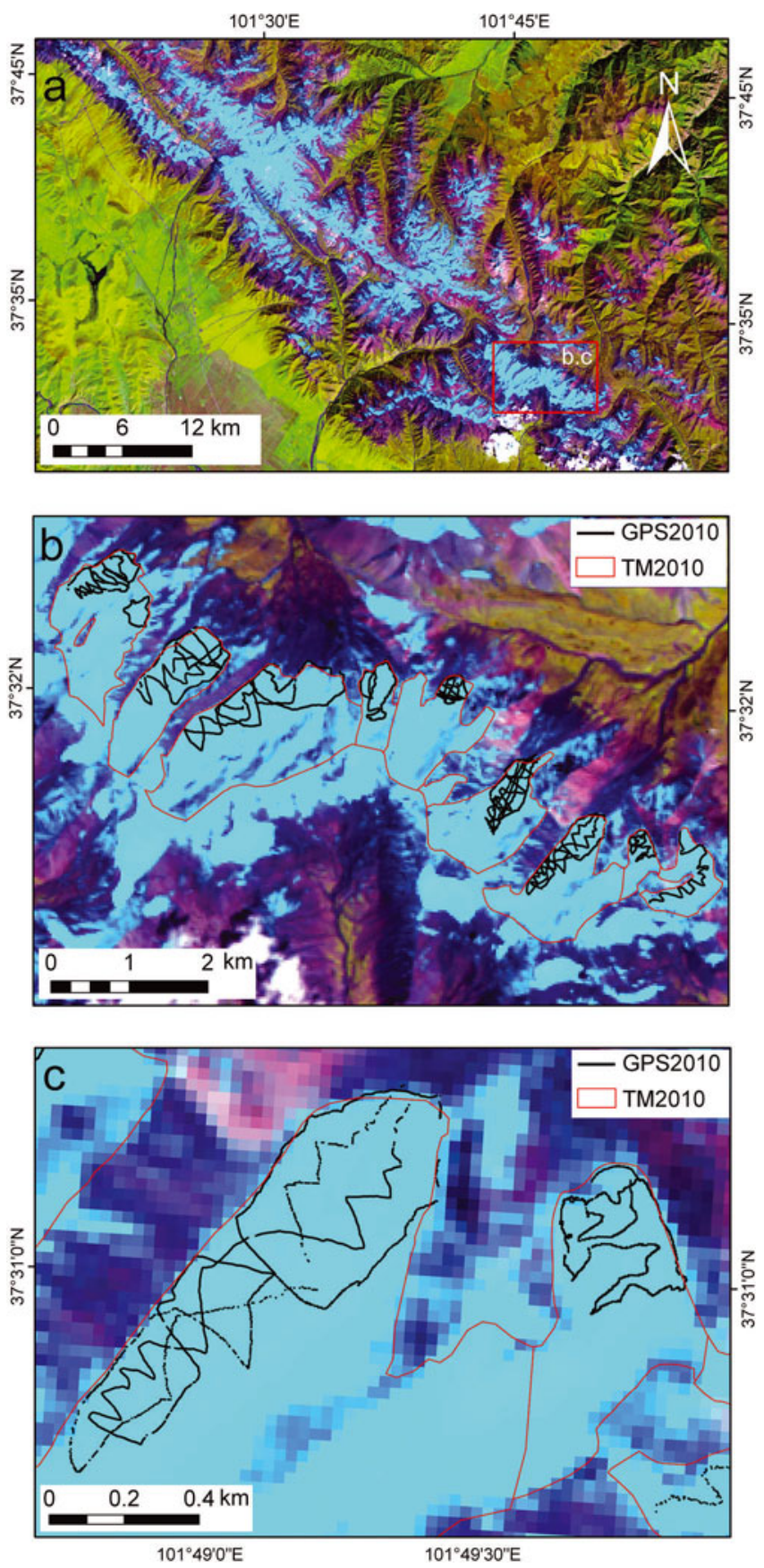

Fig. 2. (a) Overview of the western Lenglongling mountains with a Landsat TM (8 September 2010) band 5, 4, 3 (as red, green, blue) false-colour composite showing snow and ice in light blue. This image shows that the glacier was covered by seasonal snow cover. (b) The borderlines of Ningchan and Shuiguan River glaciers, which can be extracted accurately from (a). GPS-RTK data are in good agreement with the glacier borderlines. (c) Enlargement of (b).

than or equal to the threshold. The glaciers are thus represented as $1 \mathrm{~s}$ in the binary image, and the binary raster is converted to a vector for more efficient data handling during post-processing (Svoboda and Paul, 2009). However, serrated vector borderlines are not suitable to depict natural glacier boundaries, and a specially designed procedure to smooth the lines is needed. The basic idea is to connect the midpoints of each line segment that has a length equal to single cell size, remove vertexes of line segments that have equal slopes, then offset the two end-points of line segments that are longer than single cell size towards the middle of the line with half cell-size distance. However, this may lead to negative errors $(\sim 1-2 \%)$ in the glacier area attribute.

\section{Manual digitization}

Although the band ratio method is robust and the results are very accurate for debris-free ice (Andreassen and others, 2008; Paul and Andreassen, 2009), it is difficult to automatically distinguish debris-covered ice from its surroundings as the spectral characteristics are close (Paul and others, 2004a). The best tool to extract more reliable information from satellite images for many glaciers is manual digitization (Raup and others, 2007). All glaciers in the western Lenglongling mountains are debris-free and the glacier borderlines only occasionally need manual modification, relying on the DEM. However, in order to reduce the impact of subjective factors on precision in the process of manual digitization, we chose three experts to perform this process independently and then ultimately integrated their results.

\section{UNCERTAINTIES IN GLACIER BORDERLINE EXTRACTION}

In order to verify the accuracy in extracting glacier borderlines from satellite images, a GPS real-time kinematic (GPS-RTK) measurement for Ningchan and Shuiguan River glaciers was performed in July 2010. The precision of the vertical and horizontal measurements by GPS was approximately 0.1 and $0.05 \mathrm{~m}$, respectively. When applied to glacier area, for some unclear reason (e.g. clouds, ionosphere error) the precision may decrease. However, the accuracy will be restricted by an accuracy of $0.3 \mathrm{~m}$ in the vertical and $0.1 \mathrm{~m}$ in the horizontal (Rivera and others, 2005). A TM image (path 132, row 34, 8 September 2010) that is coincident with the GPS-RTK measurement was obtained to verify the accuracy in mapping the glacier borderline. However, it was not possible to extract the complete glacier borderline from this TM image due to interference by seasonal snow cover (Fig. 2a), so the 2010 TM was only considered as a reference for glacier borderline verification rather than a data source. Fortunately, however, some parts of the glacier in this image (e.g. Ningchan and Shuiguan River glaciers) can be distinguished clearly from other surface types (Fig. 2b). For these glaciers, the borderlines extracted from the TM image in 2010 are in good agreement with the GPS-RTK measurements in 2010 (Fig. 2c). Therefore, in the western Lenglongling mountains, we believe the band ratio method for extracting a glacier borderline from satellite images is an accurate and reliable approach. In addition, the glacier extents outlined by GPSRTK in 2010 are inside the borderlines extracted from the ASTER image in 2007. This result indicates that the trend in glacier variation from 2007 to 2010 is retreat, similar to that of 1972-2007.

The accuracy in measuring glacier terminus positions extracted from multitemporal satellite images primarily relies on the sensor resolutions (Williams and others, 1997) and the co-registration errors (Hall and others, 2003; Silverio and Jaquet, 2005). Therefore, an uncertainty will probably occur in this measurement. According to Silverio and Jaquet (2005) and Ye and others (2006), this uncertainty can be calculated from

$$
U_{\mathrm{T}}=\sqrt{\sum \lambda^{2}}+\sqrt{\sum \varepsilon^{2}}
$$




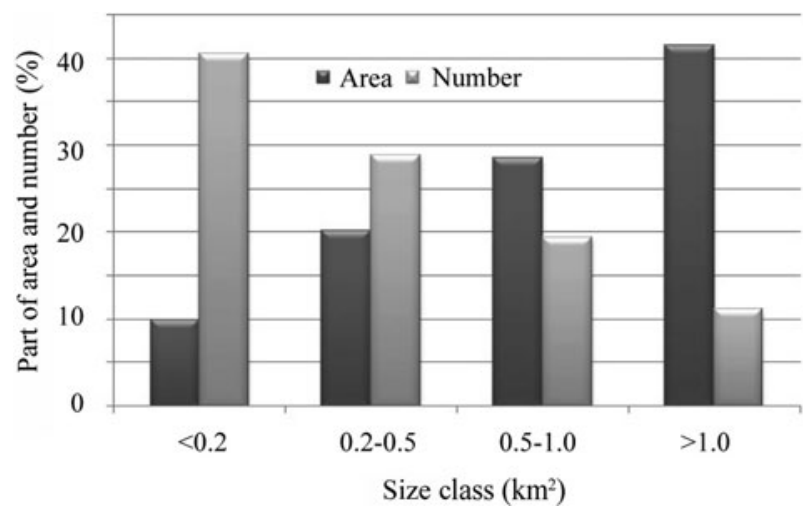

Fig. 3. Bar graph showing the glacier area and number frequency (total $=100 \%$ ) per size class.

where $U_{T}$ is the measurement uncertainty of the glacier terminus in the study area, $\lambda$ is the original pixel resolution of each image and $\varepsilon$ is the co-registration error of each image to the topographic map generated in 1972 . For the images in 1972, 1995, 1999, 2000, 2002 and 2007, the resolutions are 5.00, 28.50, 14.25, 19.60, 14.25 and $15.00 \mathrm{~m}$, respectively. As a result, according to Eqn (1), the uncertainties in our glacier tongue measurements were $57.4 \mathrm{~m}$ between 1972 and 1995, 63.7 m between 1995 and 1999, $40.3 \mathrm{~m}$ between 1999 and 2002, $41.3 \mathrm{~m}$ between 2002 and 2007 and $30.8 \mathrm{~m}$ between 1972 and 2007. The total $U_{\mathrm{T}}$ among the data sources is $86.9 \mathrm{~m}$.

According to Ye and others (2006) the co-registration error also plays an important role in variation measurement between datasets. Therefore, we introduce the co-registration error into the accuracy evaluation in our glacier extent calculation. The uncertainty in calculating the variation in extent of the 179 glaciers in the western Lenglongling mountains from 1972 to 2007 can be evaluated to be $0.009 \mathrm{~km}^{2}$, i.e.

$$
U_{\mathrm{A}}=2 U_{\mathrm{T}} \sqrt{\sum \lambda^{2}}+\sum \varepsilon^{2}
$$

where $U_{\mathrm{A}}$ is the uncertainty in calculating glacier extent.

Considering the small values of $U_{\mathrm{T}}$ and $U_{\mathrm{A}}$, the uncertainty in mapping the glacier borderline from multitemporal satellite images is negligible.

\section{RESULTS}

\section{Glacier size and distribution}

From the aerial photographs, the 179 glaciers in the study area covered a total area of $86.2 \mathrm{~km}^{2}$ (average glacier area $\sim 0.48 \mathrm{~km}^{2}$ ) in 1972 . There is a strong asymmetry between relatively large glaciers and smaller glaciers in glacier number and area (Fig. 3). Glaciers smaller than $0.5 \mathrm{~km}^{2}$ account for $69 \%$ of the total number of glaciers in the western Lenglongling mountains, yet represent just 30\% of the total glacier area in the region. In contrast, although the larger glaciers (i.e. those larger than $1 \mathrm{~km}^{2}$ ) constitute just $11.1 \%$ of the total number, they represent $41.4 \%$ of the total glacier area. The discrepancy with the CGI estimate of $87.2 \mathrm{~km}^{2}$ (Wang and others, 1981; Shi and others, 2005) can probably be attributed to the different data source and errors in manual processing of glacier borderlines.

The mean slope and aspect of each glacier have been calculated (Fig. 4). Generally, the glaciers in the study area

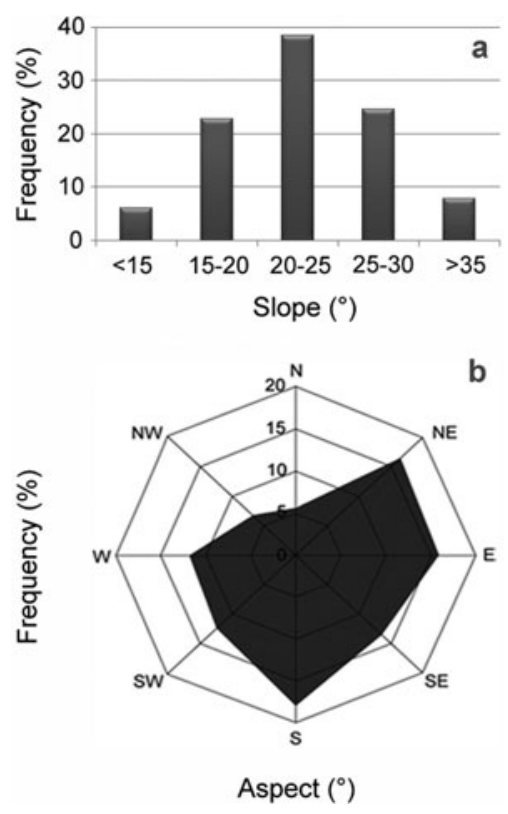

Fig. 4. (a) Bar graph showing the glacier slope frequency (total= $100 \%$ ) per size class. (b) Rose diagram showing the glacier aspect frequency (total $=100 \%$ ) per size class.

are steep, with a mean slope of $23^{\circ}$, and slopes are close to normally distributed. The studied glaciers are oriented in all directions, but the two predominant aspects are south and east.

\section{Glacier change}

All 179 glaciers in the western Lenglongling mountains shrunk between 1972 and 2007 (Fig. 5). The total glacierized area was 86.2, 70.5, 66.9, 64.6 and $61.8 \mathrm{~km}^{2}$ in 1972, 1995, 1999, 2002 and 2007, respectively (Table 2). Total area decreased significantly, with a total area loss of $24.4 \mathrm{~km}^{2}$, equivalent to $28.3 \%$ of the original area in 1972. The mean rate of area reduction was $0.70 \mathrm{~km}^{2} \mathrm{a}^{-1}$, but the shrinkage rates in different time periods are inconsistent. The annual shrinkage rate of the glacier area from 1995 to 2002 was faster than in other intervals.

Based on the different size categories derived from the standard in 1972 (Fig. 3), total glacier area change with time within each category is shown in Table 3. Glaciers with an area less than $0.1 \mathrm{~km}^{2}$ in 1972 lost $\sim 67.2 \%$ of their area between 1972 and 2007. Glaciers with an area of 0.1-0.2 $\mathrm{km}^{2}$ in 1972 decreased by $70.3 \%$, while the larger glaciers $\left(>1 \mathrm{~km}^{2}\right)$ lost $14.3 \%$ of their total area. In summary, the

Table 2. Changes of glacier areas in the western Lenglongling mountains between 1972 and 2007

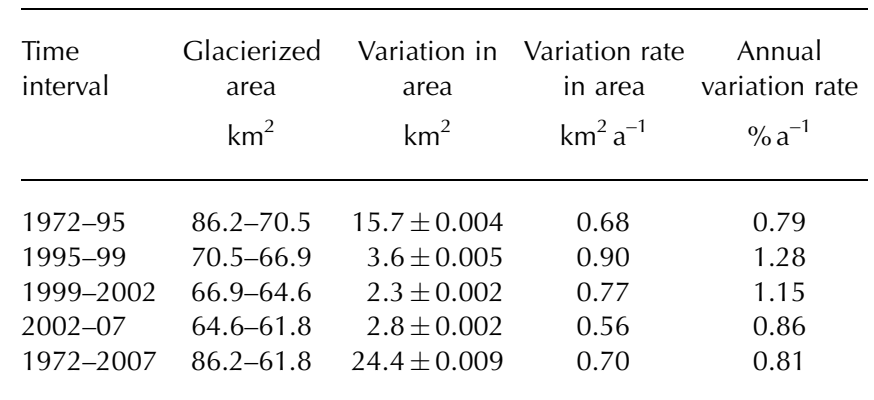




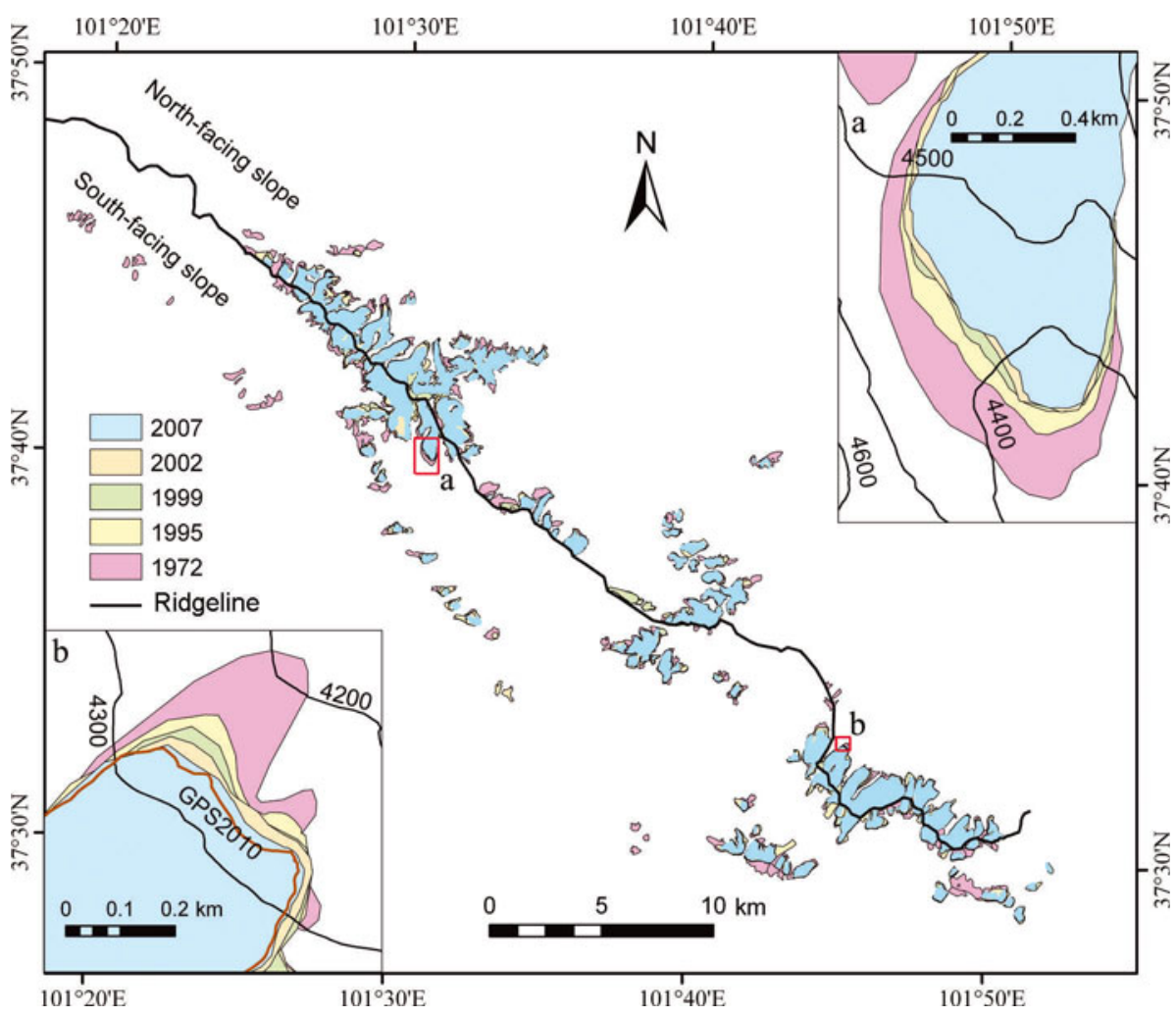

Fig. 5. Glacier borderlines of the western Lenglongling mountains in 1972, 1995, 1999, 2002 and 2007 as shown by different colors. Glaciers are divided into those with south-facing slope and those with north-facing slope by ridgeline. Details of two glacier terminus positions (A and B) are also shown.

relatively small glaciers of the western Lenglongling mountains decreased faster than the larger glaciers. This significant discrepancy in rate of decrease may arise from the fact that the small glaciers have smaller altitudinal range (Racoviteanu and others, 2008b). As a result, local climate fluctuations may result in the ELAs increasing to above the glacier maximum elevation, so that the entire area occupied by the glacier is within the ablation zone (Kaser and Osmaston, 2002).

By using the DEM to define drainage basins, we see that the glaciers of the western Lenglongling mountains can be separated into two categories: those with southwest-facing slopes and those with northeast-facing slopes. Between 1972 and 2007, the annual area variation rate of glaciers facing southwest was $0.41 \mathrm{~km}^{2}$, significantly greater than for those facing northeast $\left(0.28 \mathrm{~km}^{2}\right.$; Table 4$)$.

Table 3. Total glacier areas $\left(\mathrm{km}^{2}\right)$ within different size categories $\left(\mathrm{km}^{2}\right)$ between 1972 and 2007

\begin{tabular}{lccccc}
\hline Year & \multicolumn{5}{c}{ Glacier area } \\
& $<0.1$ & $0.1-0.2$ & $0.2-0.5$ & $0.5-1.0$ & $>1.0$ \\
\hline 1972 & 1.83 & 6.73 & 17.53 & 24.51 & 35.47 \\
1995 & 0.77 & 2.66 & 12.75 & 20.64 & 32.68 \\
1999 & 0.71 & 2.44 & 12.05 & 19.82 & 32.05 \\
2002 & 0.64 & 2.23 & 11.45 & 19.03 & 31.25 \\
2007 & 0.60 & 2.00 & 9.61 & 17.24 & 30.41 \\
Glacier changes & 67.2 & 70.3 & 45.2 & 29.7 & 14.3 \\
$1972-2007$ (\%) & & & & &
\end{tabular}

\section{RELATIONSHIP BETWEEN GLACIER VARIATION AND CLIMATE CHANGE}

The key to understanding the mechanisms of glacier variation likely lies in a thorough analysis of glacier response to climate change (Dyurgerov and Meier, 2000; Anderson and others, 2008). Instrumental records are available from only a few meteorological stations in western China, especially in mountainous regions. Four meteorological stations have been established in the region of the western Lenglongling mountains (Fig. 1). Menyuan $\left(37^{\circ} 23^{\prime} \mathrm{N}\right.$, $101^{\circ} 37^{\prime} \mathrm{E} ; 2924 \mathrm{ma}$ a.s.l.) and Jiutiaoling $\left(37^{\circ} 50^{\prime} \mathrm{N}\right.$, $102^{\circ} 01^{\prime} \mathrm{E} ; 2350 \mathrm{~m}$ a.s.l.) meteorological stations are closer to the glaciers in the study area than are Wushaoling $\left(37^{\circ} 12^{\prime} \mathrm{N}, 102^{\circ} 52^{\prime} \mathrm{E} ; 3044 \mathrm{~m}\right.$ a.s.l. $)$ and Wuwei $\left(37^{\circ} 55^{\prime} \mathrm{N}\right.$, $102^{\circ} 40^{\prime} \mathrm{E} ; 1532 \mathrm{~m}$ a.s.l.) stations. Menyuan and Wushaoling stations are located respectively south and east of the western Lenglongling mountains, while Jiutiaoling and Wuwei stations are to the north. Meteorological data are available from the China Meteorological Data Sharing Service System (http://cdc.cma.gov.cn/).

Analyzing data from the above four meteorological stations, we find that during the past six decades the annual precipitation seems to show a stable pattern, which can be well represented by roughly parallel fitting lines (Fig. 6). The precipitation on the south-facing slope of the western Lenglongling mountains shows a negligible decrease (Menyuan station), while it appears to slightly increase on the north-facing slope (Jiutiaoling and Wuwei stations). Compared with the low precipitation trend, air temperature seems to display a dramatic increasing pattern (Fig. 7). Menyuan station is the closest of the four to the glaciers in our study area, and the pattern of air temperature reflected by the data 


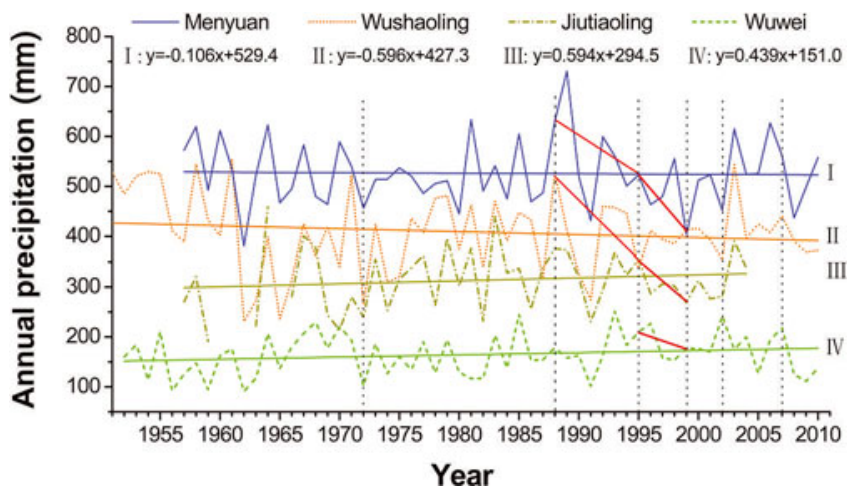

Fig. 6. Annual precipitation. Data sources are the four meteorological stations: Menyuan, Wushaoling, Jiutiaoling and Wuwei.

from this station is probably consistent with the actual pattern over the glaciers. In comparison with the global average air temperature increase between 1950 and 2000, $\sim 1^{\circ} \mathrm{C}(100 \mathrm{a})^{-1}$ (Houghton and others, 2001), the increase in air temperature in the western Lenglongling mountains from 1957 to 2010 is $\sim 3.7$ times greater. While inevitably there is a time lag in the response of a glacier to climate change, the lag is expected to be discrepant for different glacier sizes. According to Yao and others (2004), the smaller and shorter glaciers will probably respond more rapidly to climate change. Most glaciers of the western Lenglongling mountains are relatively small, with individual areas of $<1 \mathrm{~km}^{2}$, and the reaction time for most mountain glaciers is expected to be $<10$ years (Paterson, 1994; Ren and others, 2006). In summary, the glacier shrinkage in the western Lenglongling mountains from 1972 to 2007 can probably be attributed to the dramatic increase in air temperature.

The rate of glacier shrinkage in the study area was $0.90 \mathrm{~km}^{2} \mathrm{a}^{-1}$ from 1995 to 1999 and $0.77 \mathrm{~km}^{2} \mathrm{a}^{-1}$ from 1999 to 2002. The precipitation from 1988 to 1995 exhibits a decreasing trend at Menyuan, Wushaoling and Jiutiaoling stations (Fig. 6), while air temperature recorded by all meteorological stations exhibited a stable pattern (Fig. 7). The precipitation from 1995 to 1999 shows a decreasing trend at Menyuan, Wushaoling and Jiutiaoling stations (Fig. 6), while air temperature recorded by all stations indicates a relatively rapid increase (Fig. 7). Thus, the higher glacier shrinkage rate from 1995 to 2002 in the western Lenglongling mountains may result from the combination of decreasing precipitation and increasing air temperature from 1988 to 1999 . The clear correspondence between glacier shrinkage and climate change suggests that the lag in a glacier's reaction to climate change is probably $\sim 5-8$ years.
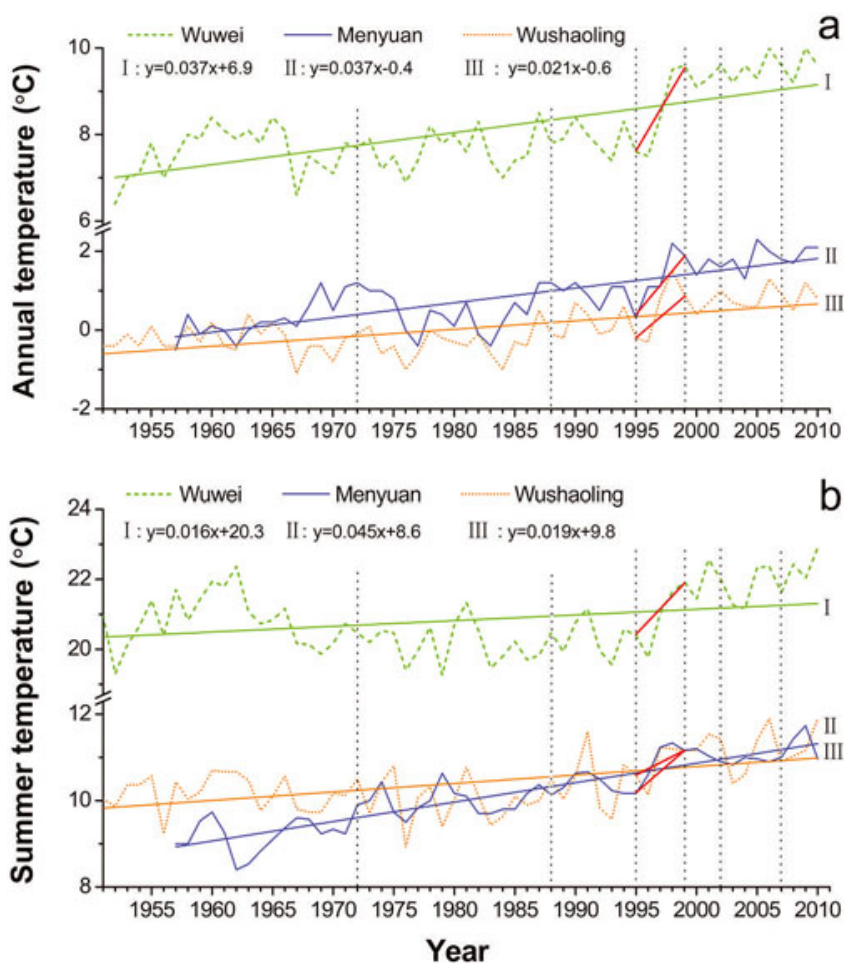

Fig. 7. Mean air temperature. (a) Annual air temperature and (b) summer (June-August) air temperature.

The glacier shrinkage rate on the southwest-facing slope of the western Lenglongling mountains is faster than on the northeast-facing slope, likely for three reasons. First, the precipitation shows a slight decreasing trend on the southwest-facing slope, yet a small increasing trend on the northeast-facing slope (Fig. 6). Second, the rate of increase in summer air temperature (June-August) on the south-facing slope is $\sim 4.5^{\circ} \mathrm{C}(100 \mathrm{a})^{-1}$, two to three times higher than on the northeast-facing slope $\left(\sim 1.6^{\circ} \mathrm{C}(100 \mathrm{a})^{-1}\right)$, although the increase in annual air temperature on the two sides of the mountains seems to be the same (Fig. 7b). According to Gardner and others (2011), an increase in glacier mass loss is probably a direct response of the glacier to higher air temperature in summer. Thirdly, the average glacier size on the southwest-facing slope is $0.38 \mathrm{~km}^{2}$, smaller than that $\left(0.62 \mathrm{~km}^{2}\right)$ on the northeast-facing slope.

During the past few decades, glacier change has been widely investigated, for example in Alaska (e.g. Arendt and others, 2002), Patagonia (e.g. Rignot and others, 2003), the Andes (e.g. Racoviteanu and others, 2008b), the Himalaya (e.g. Kääb, 2005) and central Asia (e.g. Bolch, 2007). Results

Table 4. Changes to glacier areas with different slope categories between 1972 and 2007

\begin{tabular}{|c|c|c|c|c|c|c|}
\hline Time intervals & $\begin{array}{c}\text { Areas on the } \\
\text { south-facing slope } \\
\mathrm{km}^{2}\end{array}$ & $\begin{array}{l}\text { Variation rate } \\
\text { in area } \\
\mathrm{km}^{2} \mathrm{a}^{-1}\end{array}$ & $\begin{array}{c}\text { Annual } \\
\text { variation rate } \\
\% \mathrm{a} \mathrm{a}^{-1}\end{array}$ & $\begin{array}{c}\text { Areas on the } \\
\text { north-facing slope } \\
\mathrm{km}^{2}\end{array}$ & $\begin{array}{l}\text { Variation rate } \\
\text { in area } \\
\mathrm{km}^{2} \mathrm{a}^{-1}\end{array}$ & $\begin{array}{c}\text { Annual } \\
\text { variation rate } \\
\%_{\mathrm{o} \mathrm{a}^{-1}}\end{array}$ \\
\hline 1972-95 & $38.72-28.67$ & 0.44 & 1.13 & $47.44-41.81$ & 0.24 & 0.52 \\
\hline 1995-99 & $28.67-26.86$ & 0.45 & 1.57 & $41.81-40.02$ & 0.45 & 1.07 \\
\hline 1999-2002 & $26.86-25.68$ & 0.39 & 1.46 & $40.02-38.92$ & 0.37 & 0.92 \\
\hline 2002-07 & $25.68-24.12$ & 0.31 & 1.21 & $38.92-37.71$ & 0.24 & 0.62 \\
\hline 1972-2007 & $38.72-24.12$ & 0.42 & 1.07 & $47.44-37.71$ & 0.29 & 0.59 \\
\hline
\end{tabular}


suggest that glacier retreat is now a consistent phenomenon. The degree of retreat has varied spatio-temporally by about $5-10 \%$ over the past three decades in China ( $\mathrm{Li}$ and others, 2008). According to Liu and others (2003), the total glacier area loss in the western Qilian Shan from 1956 to 1990 is $\sim 10.3 \%$. The glaciers located further into the continental interiors and at high altitudes, for example in the eastern Pamir (Shangguan and others, 2006) and the inner Tibetan Plateau (Li and others, 1998), show lower rates of glacier shrinkage. On the basis of our analysis, the 179 glaciers in the western Lenglongling mountains have lost $28.3 \%$ of their total 1972 area or $0.81 \% \mathrm{a}^{-1}$ from 1972 to 2007 . Compared with other glaciers worldwide, these glaciers present a relatively higher shrinkage rate. For example, the total glacier area loss in the Alps is $\sim 20 \%$ (Kääb and others, 2002; Paul and others, 2004b) and the glaciers of the Northern Patagonia Icefield have decreased by $\sim 3.4 \pm 1.5 \%$ from 1979 to 2001 (Rivera and others, 2007). According to Oerlemans (1994), a temperature increase of $\sim 0.1^{\circ} \mathrm{C}(10 \mathrm{a})^{-1}$ can result in a variation of several hundred meters in glacier length. The higher rate of glacier shrinkage in our study area is probably attributable to a dramatic increase in air temperature and relatively small glacier size (an average area of $0.48 \mathrm{~km}^{2}$ ).

\section{CONCLUSIONS}

We have provided a comprehensive and multitemporal analysis of glacier change in the western Lenglongling mountains. The primary data sources employed included aerial photographs, satellite images, a DEM and GPS data. The band ratio method worked well to extract glacier borderlines from satellite images. The 179 glaciers in the western Lenglongling mountains have lost $28.3 \%$ of their area in the period 1972-2007. The glacier shrinkage rates seem to be discrepant over different time intervals. A higher shrinkage rate appeared in the period 1995-2002. Compared with other glaciers worldwide, those in our study area show a higher shrinkage rate, $0.81 \% \mathrm{a}^{-1}$ from 1972 to 2007. We believe that this is a consequence of a dramatic increase in air temperature and the relatively small glacier size.

\section{ACKNOWLEDGEMENTS}

We thank T.H. Jacka and Tingjun Zhang for their help and structural improvements to the manuscript. This paper has benefited from valuable comments and constructive suggestions by Keith A. Brugger and an anonymous reviewer, whose efforts are gratefully acknowledged. This study is financially supported by the Investigation of Glacier Resource and its Variations in China (No. 2006FY110200), National Natural Science Foundation of China (No. 91125008), National Natural Science Foundation of China (No. 41171063) and National Science Foundation of China Innovation Team Project (No. 41021091).

\section{REFERENCES}

Anderson B, Lawson W and Owens I (2008) Response of Franz Josef Glacier Ka Roimata o Hine Hukatere to climate change. Global Planet. Change, 63(1), 23-30 (doi: 10.1016/j.gloplacha.2008.04.003)

Andreassen LM, Paul F, Kääb A and Hausberg JE (2008) Landsatderived glacier inventory for Jotunheimen, Norway, and deduced glacier changes since the 1930s. Cryosphere, 2(2), 131-145 (doi: 10.5194/tc-2-131-2008)
Aniya M, Sato H, Naruse R, Skvarca P and Casassa G (1996) The use of satellite and airborne imagery to inventory outlet glaciers of the Southern Patagonia Icefield, South America. Photogramm. Eng. Remote Sens., 62(12), 1361-1369

Arendt AA, Echelmeyer KA, Harrison WD, Lingle CS and Valentine VB (2002) Rapid wastage of Alaska glaciers and their contribution to rising sea level. Science, 297(5580), 382-386 (doi: 10.1126/science.1072497)

Berthier E and 7 others (2005) Surface motion of mountain glaciers derived from satellite optical imagery. Remote Sens. Environ., 95(1), 14-28 (doi: 10.1016/j.rse.2004.11.005)

Berthier E, Schiefer E, Clarke GKC, Menounos B and Rémy F (2010) Contribution of Alaskan glaciers to sea-level rise derived from satellite imagery. Nature Geosci., 3(2), 92-95 (doi: 10.1038/ ngeo737)

Bolch T (2007) Climate change and glacier retreat in northern Tien Shan (Kazahkstan/Kyrgyzstan) using remote sensing data. Global Planet. Change, 56(1-2), 1-12 (doi: 10.1016/j.gloplacha.2006. 07.009)

Cao B, Pan B, Gao H, Jing S, Wen Yand Shangguan D (2010) Glacier variation in the Lenglongling Range of Eastern Qilian Mountains from 1972 to 2007. J. Glaciol. Geocryol., 32(2), 242-248

Davis CH, Li Y, McConnell JR, Frey MM and Hanna E (2005) Snowfall-driven growth in East Antarctic ice sheet mitigates recent sea-level rise. Science, 308(5730), 1898-1901 (doi: 10.1126/science.1110662)

Delgado Granados H, Julio Miranda P, Higgel C, Ortega del Valle S and Alatorre Ibargüengoitia MA (2007) Chronicle of a death foretold: extinction of the small-size tropical glaciers of Popocatépetl volcano (Mexico). Global Planet. Change, 56(1-2), 13-22 (doi: 10.1016/j.gloplacha.2006.07.010)

Dyurgerov MB and Meier MF (1997) Mass balance of mountain and subpolar glaciers: a new global assessment for 1961-1990. Arct. Alp. Res., 29(4), 379-391

Dyurgerov MB and Meier MF (2000) Twentieth century climate change: evidence from small glaciers. Proc. Natl. Acad. Sci. USA (PNAS), 97(4), 1406-1411 (doi: 10.1073/pnas.97.4.1406)

Fairbanks RG (1989) A 17,000-year glacio-eustatic sea level record: influence of glacial melting rates on the Younger Dryas event and deep-ocean circulation. Nature, 342(6250), 637-642 (doi: $10.1038 / 342637 \mathrm{a} 0)$

Gardner AS and 8 others (2011) Sharply increased mass loss from glaciers and ice caps in the Canadian Arctic Archipelago. Nature, 473(7347), 357-360 (doi: 10.1038/nature10089)

Global Climate Observing System (GCOS) (2003) The second report on the adequacy of the Global Observing Systems for Climate in support of the UNFCCC, GCOS-82. World Meteorological Organization, Geneva (WMO/TD No. 1143)

Guo C-X, Bo M, Ji Z and Mao L (2002) The transfer model between the $\mathrm{Xi}^{\prime}$ an 80 and WGS-84 coordinate systems. Northeast Surv. Map., 25(4), 34-36 [In Chinese with English summary]

Hall DK, Benson CS and Field WO (1995a) Changes of glaciers in Glacier Bay, Alaska, using ground and satellite measurements. Phys. Geogr., 16(1), 27-41

Hall DK, Riggs GA and Salomonson VV (1995b) Development of methods for mapping global snow cover using Moderate Resolution Imaging Spectroradiometer (MODIS) data. Remote Sens. Environ., 54(2), 127-140 (doi: 10.1016/0034-4257(95) 00137-P)

Hall DK, Bayr KJ, Schöner W, Bindschadler RA and Chien JYL (2003) Consideration of the errors inherent in mapping historical glacier positions in Austria from ground and space (1893-2001). Remote Sens. Environ., 86(4), 566-577 (doi: 10.1016/S00344257(03)00134-2)

Houghton JT and 7 others eds (2001) Climate change 2001: the scientific basis. Contribution of Working Group I to the Third Assessment Report of the Intergovernmental Panel on Climate Change. Cambridge University Press, Cambridge

Jiang H, Strittholt JR, Frost PA and Slosser NC (2004) The classification of late seral forests in the Pacific Northwest, 
USA, using Landsat ETM+ imagery. Remote Sens. Environ. 91(3-4), 320-331 (doi: 10.1016/j.rse.2004.03.016)

Jin R, Xin L, Che T, Wu L and Mool P (2005) Glacier area changes in the Pumqu river basin, Tibetan Plateau, between the 1970s and 2001. J. Glaciol., 51(175), 607-610 (doi: 10.3189/ 172756505781829061)

Kääb A (2005) Combination of SRTM3 and repeat ASTER data for deriving alpine glacier flow velocities in the Bhutan Himalaya. Remote Sens. Environ., 94(4), 463-474 (doi: 10.1016/j.rse.2004. 11.003)

Kääb A, Paul F, Maisch M, Hoelzle M and Haeberli W (2002) The new remote-sensing-derived Swiss glacier inventory: II. First results. Ann. Glaciol., 34, 362-366 (doi: 10.3189/ 172756402781817473)

Kaser G and Osmaston H (2002) Tropical glaciers. Cambridge University Press, Cambridge

Li X and 9 others (2008) Cryospheric change in China. Global Planet. Change, 62(3-4), 210-218 (doi: 10.1016/j.gloplacha. 2008.02.001)

Li Z, Sun W and Zeng Q (1998) Measurement of glacier variation in the Tibetan Plateau using Landsat data. Remote Sens. Environ., 63(3), 258-264 (doi: 10.1016/S0034-4257(97)00140-5)

Lillesand TM and Kiefer RW (1999) Remote sensing and image interpretation, 4th edn. Wiley, New York

Liu JG (2000) Evaluation of Landsat-7 ETM+ panchromatic band for image fusion with multispectral bands. Natur. Resour. Res., 9(4), 269-276 (doi: 10.1023/A:1011553209310)

Liu S, Sun W, Shen Y and Li G (2003) Glacier changes since the Little Ice Age maximum in the western Qilian Shan, northwest China, and consequences of glacier runoff for water supply. J. Glaciol., 49(164), 117-124 (doi: 10.3189/ 172756503781830926)

Narama C, Shimamura Y, Nakayama D and Abdrakhmatov K (2006) Recent changes of glacier coverage in the western TerskeyAlatoo range, Kyrgyz Republic, using Corona and Landsat. Ann. Glaciol., 43 223-229 (doi: 10.3189/172756406781812195)

Oerlemans J (1994) Quantifying global warming from the retreat of glaciers. Science, 264(5156), 243-245

Oerlemans J and 10 others (1998) Modelling the response of glaciers to climate warming. Climate Dyn., 14(4), 267-274 (doi: 10.1007/s003820050222)

Pachauri RK and Reisinger A eds (2007) Climate change 2007: Synthesis Report. Contribution of Working Groups I, II and III to the Fourth Assessment Report of the Intergovernmental Panel on Climate Change. Intergovernmental Panel on Climate Change, Geneva

Paterson WSB (1994) The physics of glaciers, 3rd edn. Elsevier, Oxford

Paul F (2001) Evaluation of different methods for glacier mapping using Landsat TM. EARSeL eProc., 1(1), 239-245

Paul F and Andreassen LM (2009) A new glacier inventory for the Svartisen region, Norway, from Landsat ETM+ data: challenges and change assessment. J. Glaciol., 55(192), 607-618 (doi: 10.3189/002214309789471003)

Paul F, Huggel C and Kääb A (2004a) Combining satellite multispectral image data and a digital elevation model for mapping debris-covered glaciers. Remote Sens. Environ., 89(4), 510-518 (doi: 10.1016/j.rse.2003.11.007)

Paul F, Kääb A, Maisch M, Kellenberger T and Haeberli W (2004b) Rapid disintegration of Alpine glaciers observed with satellite data. Geophys. Res. Lett., 31(21), L21402 (doi: 10.1029/ 2004GL020816)

Paul F, Kääb A and Haeberli W (2007) Recent glacier changes in the Alps observed from satellite: consequences for future monitoring strategies. Global Planet. Change, 56(1-2), 111-122

Racoviteanu AE, Williams MW and Barry RG (2008a) Optical remote sensing of glacier characteristics: a review with focus on the Himalaya. Sensors, 8(5), 3355-3383 (doi: 10.3390/s8053355)

Racoviteanu $A E$, Arnaud Y, Williams MW and Ordoñez J (2008b) Decadal changes in glacier parameters in the Cordillera
Blanca, Peru, derived from remote sensing. J. Glaciol., 54(186), 499-510

Raup B and 11 others (2007) Remote sensing and GIS technology in the Global Land Ice Measurements from Space (GLIMS) Project. Comput. Geosci., 33(1), 104-125 (doi: 10.1016/j.cageo.2006. 05.015)

Ren J, Jing Z, Pu J and Qin X (2006) Glacier variations and climate change in the central Himalaya over the past few decades. Ann. Glaciol., 43 218-222 (doi: 10.3189/172756406781812230)

Rignot E, Rivera A and Casassa G (2003) Contribution of the Patagonian icefields of South America to sea level rise. Science, 302(5644), 434-437 (doi: 10.1126/science.1087393)

Rivera A, Casassa G, Bamber JL and Kääb A (2005) Ice-elevation changes of Glaciar Chico, southern Patagonia, using ASTER DEMs, aerial photographs and GPS data. J. Glaciol., 51(172), 105-112 (doi: 10.3189/172756505781829557)

Rivera A, Benham T, Casassa G, Bamber J and Dowdeswell JA (2007) Ice elevation and areal changes of glaciers from the Northern Patagonia Icefield, Chile. Global Planet. Change, 59(1-4), 126-137 (doi: 10.1016/j.gloplacha.2006.11.037)

Shangguan D and 9 others (2006) Monitoring the glacier changes in the Muztag Ata and Konggur mountains, east Pamirs, based on Chinese Glacier Inventory and recent satellite imagery. Ann. Glaciol., 43, 79-85 (doi: 10.3189/172756406781812393)

Shangguan D and 8 others (2007) Glacier changes in the west Kunlun Shan from 1970 to 2001 derived from Landsat TM/ETM+ and Chinese glacier inventory data. Ann. Glaciol., 46, 204-208 (doi: 10.3189/172756407782871693)

Shangguan D and 6 others (2010) Changes in the elevation and extent of two glaciers along the Yanglonghe river, Qilian Shan, China. J. Glaciol., 56(196), 309-317 (doi: 10.3189/ 002214310791968566)

Shi Y and Liu S (2000) Estimation on the response of glaciers in China to the global warming in the 21 st century. Chinese Sci. Bull., 45(7), 668-672 (doi: 10.1007/BF02886048) [In Chinese]

Shi Y, Liu C, Wang Z, Liu S and Ye B eds (2005) A concise glacier inventory of China. Shanghai Science Popularization Press, Shanghai [in Chinese]

Sidjak RW and Wheate RD (1999) Glacier mapping of the Illecillewaet icefield, British Columbia, Canada, using Landsat TM and digital elevation data. Int. J. Remote Sens., 20(2), 273-284

Silverio W and Jaquet J-M (2005) Glacial cover mapping (19871996) of the Cordillera Blanca (Peru) using satellite imagery. Remote Sens. Environ., 95(3), 342-350 (doi: 10.1016/j.rse.2004. 12.012)

Svoboda F and Paul F (2009) A new glacier inventory on southern Baffin Island, Canada, from ASTER data: I. Applied methods, challenges and solutions. Ann. Glaciol., 50(53), 11-21 (doi: 10.3189/172756410790595912)

Tang M and Xu M (1984) The climate change of Qilian Shan. Plateau Meteorol., 3(4), 21-33 [In Chinese]

Van Westen CJ and Lulie Getahun F (2003) Analyzing the evolution of the Tessina landslide using aerial photographs and digital elevation models. Geomorphology, 54(1-2), 77-89 (doi: 10.1016/S0169-555X(03)00057-6)

Vuille $M$ and 6 others (2008) Climate change and tropical Andean glaciers: past, present and future. Earth-Sci. Rev., 89(3-4), 79-96 (doi: 10.1016/j.earscirev.2008.04.002)

Wang JX, Wang J and Lu CP (2003) Problem of coordinate transformation between WGS-84 and BEIJING 54. J. Geod. Geodyn., 23(3), 70-73 [in Chinese]

Wang $N$ and 6 others (2009) Study on the zone of maximum precipitation in the north slopes of the central Qilian Mountains. J. Glaciol. Geocryol., 31(3), 395-403 [in Chinese]

Wang Z, Liu C, You G, Pu J, Yang H and Tian P eds (1981) Glacier inventory of China I. Qilian mountains. Science Press. Academia Sinica, Lanzhou Institute of Glaciology and Cryopedology, Beijing [in Chinese] 
Williams RS, Jr, Hall DK and Chien JYL (1997) Comparison of satellite-derived with ground-based measurements of the fluctuations of the margins of Vatnajökull, Iceland, 1973-92. Ann. Glaciol., 24, 72-80

Yang L, Xia D and Chen F (2007) On fusion algorithms of Landsat 7 ETM+ Pan and multi-spectral images. J. Lanzhou Univ. (Natur. Sci.), 43(4), 7-11 [in Chinese]

Yang Z and Zeng Q eds (2001) Glacier hydrology. Chongqing Press, Chongqing [In Chinese]

Yao TD, Wang YQ, Liu SY, Pu JC, Shen YP and Lu AX (2004) Recent glacial retreat in High Asia in China and its impact on water resource in Northwest China. Sci. China D, 47(12), 1065-1075
Ye Q, Kang S, Chen Fand Wang J (2006) Monitoring glacier variations on Geladandong mountain, central Tibetan Plateau, from 1969 to 2002 using remote-sensing and GIS technologies. J. Glaciol., 52(179), 537-545 (doi: 10.3189/172756506781828359)

Zhang H, Lu AX, Wang LH, Guo ZM and Zhang CW (2010a) Glacier change in the Lenglongling Mountain monitored by remote sensing. Remote Sens. Tech. Appl., 25(6), 682-686 [in Chinese]

Zhang Y, Fujita K, Liu S, Liu Q and Wang X (2010b) Multi-decadal ice-velocity and elevation changes of a monsoonal maritime glacier: Hailuogou glacier, China. J. Glaciol., 56(195), 65-74 (doi: 10.3189/002214310791190884)

MS received 15 February 2012 and accepted in revised form 26 April 2012 